\title{
El derecho de la niñez y la adolescencia a ser escuchada en la justicia de familia en
} Nicaragua 5

\author{
Xiomara Rivera Zamora \\ Juez de Familia, Nicaragua \\ xiriza@hotmail.com
}

Fecha de recibido: diciembre 2017 / Fecha de aprobación: abril 2018

\section{Resumen}

Este trabajo hace un abordaje doctrinario, jurisprudencial, normativo supranacional, de derecho comparado y del ordenamiento jurídico nicaragüense, sobre el derecho del niño, niña o adolescente a ser escuchado, en particular; sobre su manifestación en el proceso jurisdiccional familiar. Luego se examina la práctica jurisdiccional familiar, de judicaturas de primera instancia, en distintos polos geográficos y de un Tribunal de segunda instancia de la capital, en Nicaragua. Dicho análisis ha permitido identificar vacíos legales, aciertos y desaciertos en la puesta en práctica del referido derecho, por ello; se ofrecen algunas pautas de actuación para la homogenización en su implementación, por constituir una garantía procesal para niños, niñas o adolescentes en la justicia de familia nicaragüense.

\section{Palabras Clave}

Derecho del niño, niña o adolescente a ser escuchado/ interés superior del niño / autoridad parental / cuido y crianza / adopción

This work makes a doctrinal approach, jurisprudential, supranational normative, comparative law and the Nicaraguan legal order, on the right of the child or adolescent to be heard, in particular; on their manifestation in the family jurisdictional process. It then examines the family jurisdictional practice of first instance judges in different geographic poles and a second instance court in the capital in Nicaragua. This analysis has allowed us to identify legal gaps, successes and failures in the implementation of this right, for this reason; some guidelines of action for the homogenization in its implementation are offered, as it constitutes a procedural guarantee for children and adolescents in the Nicaraguan family court.

\section{Keywords}

Right of the child or adolescent to be heard / superior interest of the child / parental authority / care and upbringing / adoption

\footnotetext{
${ }^{5}$ Investigación realizada en el marco del Programa de Doctorado "Cuestiones actuales del Derecho" 2da edición de la Universidad Centroamericana (UCA), Nicaragua.
} 


\section{Tabla de Contenido}

Introducción. 1. El derecho del niño, niña y adolescente a ser escuchado y que su opinión sea considerada. 2. Relación entre el derecho a ser escuchado e interés superior del niño, niña y adolescente. 3 . El derecho del niño, niña y adolescente a ser escuchado en el ordenamiento jurídico familiar nicaragüense. 3.1. Necesidad de escuchar al niño, niña y adolescente. 3.2. Instrumentos legales para la materialización del derecho a ser escuchado. a. Entrevista judicial. b. Estudio psicosocial. c. Representación legal. c.1. Representación por los Progenitores. c.2. Representación del Estado. 4. EI derecho del niño, niña y adolescente a ser escuchado en la práctica jurisdiccional familiar nicaragüense. Conclusiones. Referencias bibliográficas

\section{Introducción}

El Derecho del niño, niña o adolescente a ser escuchado está contenido en la Convención Internacional sobre de los Derechos del Niño de 1989, en los sucesivo CDN, cuyo instrumento internacional de derechos humanos de la niñez y la adolescencia tiene plena vigencia en el derecho interno nicaragüense desde el año 1990 en que el Estado de Nicaragua lo ratificó y constitucionalizó en el año 1995 a través de la reforma constitucional producida por la Ley 192, Ley de reforma parcial a la Constitución Política de Nicaragua, que adicionó el art. 7I constitucional.

Como producto de este compromiso internacional, Nicaragua promulgó en 1998, el Código de la niñez y la adolescencia, en adelante CNA, cuyo objeto es el de garantizar protección integral a las niñas, niños y adolescentes por parte de la familia, la sociedad, el Estado e instituciones privadas inclusive y si bien abarca a aquellas personas que no han alcanzado los 18 años de edad, califica como niños y niñas, a quienes no han cumplido los 13 años de edad y adolescentes a los que están comprendidos entre los 13 y los 18 años de edad no cumplidos, siendo este el cuerpo normativo que ha guiado la actuación administrativa y jurisdiccional en todas las materias en las que los derechos de la niñez se ven implicados.

El CNA desarrolla específicamente el catálogo de derechos contenido en la CDN y el art. 17 de aquel, establece el Derecho del niño, niña o adolescente a ser escuchado en todo procedimiento judicial o administrativo que afecte sus derechos, libertades y garantías.

El primer Código de Familia aprobado en Nicaragua, data del año 20I4, en adelante CFN, el cual se encuentra vigente a partir del 8 de abril de 2015, en su art. 448 acoge el Derecho del niño, niña y adolescente a ser escuchado, en los mismos términos que se establecen en el art. 17 CNA, pero adiciona aquel; la obligatoriedad de la escucha a aquellos niños y niñas mayores de 7 años. Disposiciones normativas generadoras de problemas interpretativos de orden sistémico y funcional por antinomias derivadas de lo dispuesto por el art. I2 CDN, art. 17 CNA y art. 448 CFN y lagunosos de las dos últimas disposiciones citadas, al hacer remisiones a normativas inexistentes para la materialización de tal derecho, lo que ha propiciado la inobservancia y una heterogénea realización del derecho del niño, niña o adolescente a ser escuchado.

Por lo antes expresado, se hace necesario sustentar desde la doctrina, instrumentos internacionales sobre derechos humanos, jurisprudencia internacional y comparada, derecho comparado y el ordenamiento jurídico familiar nicaragüense, la necesidad de establecer pautas homogéneas de actuación que permitan garantizar el derecho del niño, niña o adolescente a ser 
escuchado en la práctica judicial nicaragüense, a fin de incidir en la materialización de los derechos humanos de la niñez y la adolescencia en Nicaragua, considerando también su perspectiva de la situación que le afecta y no únicamente el criterio de las personas adultas que intervienen en el proceso.

Haciendo uso del método jurídico dogmático, formalista y realista, de técnicas de investigación documental y de campo; mediante el análisis normativo, doctrinario y jurisprudencial para el cumplimiento del objetivo propuesto, este trabajo se aborda en cuatro apartados. En una primera parte contempla el Derecho del niño, niña y adolescente a ser escuchado y que su opinión se tenga en cuenta, que abarca las posturas doctrinales, convencionales, observaciones generales del Comité de los Derechos del niño y criterios jurisprudenciales relevantes, directamente vinculados al tema que nos ocupa, para su contextualización, cuya doctrina y jurisprudencia han sido seleccionadas de forma temática, sin atender a un año determinado debido a la limitación de sus resultados, sino que estuviesen comprendidos al menos en los últimos diez años, considerando distintos puntos geográficos, dado el carácter universal de la CDN.

Por la trascendencia del derecho a ser escuchado para la determinación del interés superior del niño, niña o adolescente, en un segundo apartado se aborda la relación existente entre ambos, en el plano convencional y en las Observaciones generales No. I2/2009 y No. 14/20I3, emanadas del Comité de los Derechos del niño y en el ámbito jurisprudencial, seguidamente se exponen las regulaciones del ordenamiento jurídico familiar nicaragüense, a fin de identificar fortalezas $y$ carencias normativas y en un cuarto apartado, como resultado de un trabajo de campo, se examina la práctica jurisdiccional familiar, a partir del análisis de sentencias judiciales relativas a derechos de la niñez, sobre cuido y crianza, autoridad parental y adopciones, para la constatación del Derecho del niño, niña y adolescente a ser escuchado, cuyos hallazgos dan pie a formular propuestas de actuación, debiendo adelantar desde ahora que en las adopciones; por los rigurosos requisitos normativos de esta acción procesal en el ámbito administrativo y jurisdiccional, se debe tomar el consentimiento al niño desde la fase administrativa, indicador de que los hallazgos en ésta no generarán mayores sorpresas, pero inciden de forma positiva en los resultados generales del estudio, que de excluirse, dichos resultados se tornan realmente preocupantes.

\section{EI Derecho del niño, niña y adolescente a ser escuchado y que su opinión sea considerada}

El Derecho del niño, niña o adolescente a ser escuchado tiene un carácter universal, en virtud de la ratificación o adhesión de la CDN hasta ahora, por 196 Estados a excepción de los Estados Unidos de América (Save the Children, 2016), en consecuencia vincula a todos los Estados parte.

La CDN regula el derecho de la niñez y la adolescencia a ser escuchada, en su art. 12, al establecer que:

I) Los Estados Partes en la presente Convención garantizarán al niño que esté en condiciones de formarse un juicio propio el derecho de expresar su opinión libremente en todos los asuntos que afectan al niño, teniéndose debidamente en cuenta las opiniones del niño, en función de la edad y madurez del niño.

2) Con tal fin, se dará en particular al niño oportunidad de ser escuchado en todo procedimiento judicial o administrativo que afecte al niño, ya sea directamente o por medio de un representante o de un órgano apropiado, de conformidad con las normas de procedimiento de la ley nacional. 
Con la finalidad de lograr una adecuada interpretación del contenido y alcance de este derecho y su interrelación con otros derechos contenidos en la Convención y una aplicación eficaz del mismo por los Estados partes de ésta, el Comité de los Derechos del Niño, en lo sucesivo el Comité, en su calidad de órgano encargado de examinar los avances en el cumplimiento de las obligaciones contraídas por los Estados partes de la CDN, tiene la potestad de formular sugerencias y recomendaciones generales, según los arts. 43 al 45 de ésta. En tal carácter el Comité ha formulado la Observación General No. 12/2009, nominada: "El derecho del niño a ser escuchado", por ser éste un criterio a considerar para la interpretación de los derechos de la niñez y la adolescencia, que según el Comité se ha visto obstaculizado y se hace necesario comprender mejor el contenido de ese derecho.

La citada Observación General No. 12/2009, hace un análisis jurídico del art. I2 CDN, es decir; del derecho del niño a ser escuchado, su vinculación con otros tres principios generales de la convención, como son; el derecho a la no discriminación, el derecho a la vida y el desarrollo y la consideración primordial de su interés superior, así también su relación con otros derechos y libertades civiles contenidos en la Convención, sin embargo aquí nos limitaremos a ver la necesaria vinculación del derecho a ser escuchado con otros principios o derechos de la Convención, en lo que hace al ejercicio del derecho a ser escuchados en el ámbito jurisdiccional familiar. En tal sentido, el Comité refiere que el párrafo primero del art. $12 \mathrm{CDN}$, regula cinco cuestiones a saber:

a) El deber de garantizar por parte de los Estados el derecho de que el niño exprese su opinión libremente, lo que no deja margen de discrecionalidad, en consecuencia los Estados deben implementar los mecanismos tendentes a respetar tal derecho y además tener en cuenta la opinión del niño, niña o adolescente.

b) La evaluación de la capacidad del niño, niña y adolescente, para formarse un juicio propio, parte de reconocer la capacidad de éste y su derecho a expresar su opinión, aún de forma no verbal, como formas de expresión de su capacidad de comprensión, de elección y de preferencias, por razones de edad, discapacidad o idiomáticas, sin que ello implique un uso indiscriminado de éste derecho, de forma reiterada o innecesaria sobre todo con niños de corta edad o víctimas de violencia.

c) El derecho del niño, niña o adolescente de expresar su opinión libremente ha de ser un acto voluntario, en el que se encuentre libre de presiones para expresar su opinión a fin de evitar efectos traumáticos en éste.

d) La opinión que ha de brindar el niño, niña o adolescente concierne a todos aquellos asuntos que le afectan, siempre que su perspectiva aumente la calidad de las soluciones a adoptar.

e) La edad y madurez del niño, niña y adolescente alude a la capacidad de éste, la cual ha de ser evaluada escuchándolo, a fin de tener o no en cuenta su opinión, sin que sea determinante su edad, sino la capacidad que tiene éste de comprender y evaluar las consecuencias de un asunto determinado, atendiendo a la evolución de sus facultades.

Sobre el derecho objeto de estudio y sobre la autonomía progresiva del niño, niña o adolescente Vargas Pavez y Correa Camus (20I I), en la doctrina chilena, expresan que:

...la autonomía progresiva se refiere a la capacidad y facultad de niños para ejercer con grados crecientes de independencia sus derechos frente al derecho-deber de los padres o adultos responsables de dirección y orientación para el ejercicio de dichos derechos. 
Implica reconocer a los niños la facultad de decidir cuándo y cómo quieren ejercer un determinado derecho, como asimismo la posibilidad de que en un momento determinado decidan no ejercerlo. [...] que uno de los riesgos de establecer un rango fijo de edad para escuchar a los niños es la rigidización en la aplicación de estos parámetros, sin considerar que los niños tienen experiencias de vida y formas de expresarse distintas. No todos los niños son iguales, por ello hay que establecer estándares flexibles, que permitan a los operadores ponderar caso a caso las condiciones del habla de los niños en función de su edad, pero también de su madurez. Lo anterior nos conduce a la necesidad de fortalecer las competencias de los operadores del sistema para oír a los niños, especialmente a los más pequeños. (p.182, 183).

Respecto del párrafo segundo del art. 12 CDN, sostiene el Comité, en la citada Observación General No. 12 (2009) que regula tres situaciones:

a) El deber de los Estados de escuchar al niño, niña o adolescente, particularmente en todo procedimiento judicial y administrativo que les afecte y de forma orientativa, no limitativa enlista algunas cuestiones relativas a: separación de los padres, custodia, cuidado y adopción, niños en conflicto con la ley, niños víctimas de violencia física o psicológica, abusos sexuales u otros delitos, atención de salud, seguridad social, niños no acompañados, niños solicitantes de asilo y refugiados y víctimas de conflictos armados y otras emergencias y en el ámbito administrativo; decisiones sobre la educación, la salud, el entorno, las condiciones de vida o la protección del niño, pero el deber de escucharlo implica contar con algunas condiciones ambientales apropiadas, no intimidatorias, ni hostiles, pudiendo hacer uso de pantallas de protección, que la entrevista se desarrolle por profesionales capacitados para tal fin, con vestuario adecuado, entre otras y que el tomador de la decisión concerniente debe justificar en qué medida ha considerado la opinión de aquel y las consecuencias de dicha opinión para sí.

b) El niño, niña y adolescente debe ser escuchado directamente $\circ$ a través de sus representantes progenitores, alertando el Comité considerar que cuando se trata de éstos, muchas veces hay conflicto de intereses. También aquel puede ser escuchado a través de abogado o de un trabajador social, quienes deben trasmitir dicha opinión al tomador de decisiones correctamente, debiendo éstos tener experiencia en el trabajo con niños y estar conscientes de que representan los intereses de éste y no los intereses de sus progenitores, para lo cual se propone la elaboración de códigos de conducta que regulen sus actuaciones.

c) Que la representación del niño, niña o adolescente obedece a las regulaciones normativas procesales de la leyes nacionales de los Estados, lo que no debe implicar restricciones al disfrute del derecho a ser escuchado, alentando el Comité a los Estados partes a cumplir con las norma básicas de imparcialidad de los procedimientos, como el derecho a la defensa, el derecho de acceder al expediente propio y el derecho a los recursos para un nuevo examen jurídico.

En el contexto de la doctrina mexicana (González Contró, 2015), aborda los derechos de la niñez y la adolescencia y en particular el derecho a ser escuchado y argumenta que: "El protagonismo del niño en la sociedad $y$ en concreto en la familia supone darle una nueva voz $y$ escucharle como un derecho en sí mismo, pero también como criterio para la interpretación de sus intereses y derechos" (p.77). 
Abboud Castillo (2016), en un estudio sobre custodia compartida, en Nicaragua, en relación al derecho de la niñez a ser escuchada, sostiene que:

...en aquellos ordenamientos jurídicos en los que la vía notarial sea apta para acuerdos de cuidado personal de los hijos e hijas, se dispongan de protocolos de actuación que establezcan la forma de incorporar la escucha de los niños, las niñas y los adolescentes, en atención a su capacidad progresiva en el acto notarial y además que formule las situaciones en las que el/la notario/a deberá abstenerse de actuar por advertir potenciales vulneraciones a intereses de legítima tutela. (p.II6)

La opinión del niño, niña o adolescente tendrá menor o mayor peso según su edad y madurez, y a las circunstancias personales, familiares y sociales en las que éste se encuentra. En la medida en que crece, se desarrolla, va adquiriendo mayor autonomía y madurez, mayor peso ha de tener su opinión, para la adopción de la decisión que afecte sus derechos, hasta llegar al punto de que su opinión sea determinante para la decisión a adoptar, dada la progresividad en el ejercicio de sus derechos, siempre que éstos no se vean vulnerados, como diría Herrera (20I I): “...a mayor autonomía o ejercicio de derechos por parte de los propios niños o adolescentes en atención a su madurez, menor representación legal..., a mayor participación de los hijos menor protagonismo de los padres,..." (p.43).

La misma corriente doctrinaria adopta Kemelmajer de Carlucci y Molina de Juan (2015):

...a mayor autonomía, menor es el ámbito de actuación del representante. [...] A menor capacidad progresiva, mayor discrecionalidad judicial porque cuando el niño no tiene madurez suficiente..., tal carencia debe ser suplida por el juez. [...] si bien la opinión de la persona menor de edad no es determinante de la decisión, cuando el juez decide apartarse de su voluntad debe ofrecer argumentos de peso que la justifiquen (pp. 3, 6 y 14).

Postura doctrinaria que han sostenido en el ámbito argentino las autoras antes referidas y en el ámbito cubano y como criterio jurisprudencial argentino, al afirmar que no es aceptable el deseo incondicional del niño cuando haya de resultar perjudicial para su formación y su real interés (Kemelmajer de Carlucci y Pérez Gallardo, 2006).

En el contexto iberoamericano y europeo existe abundante jurisprudencia sobre el derecho de la niñez y la adolescencia a ser escuchada, en cuyas sentencias se han sentado criterios de gran relevancia sobre la materialización de los derechos humanos de la niñez y adolescencia, por emanar de tribunales de segunda instancia o de los tribunales supremos de los países de donde proceden y de las mismas Cortes internacionales de derechos humanos, criterios que podemos sintetizar así:

a. Nulidad del procedimiento, revocación de resoluciones y condena por vulneración del derecho del niño, niña o adolescente a ser escuchado

Es el criterio que sostuvo la Corte Suprema de Chile, por Sentencia No. 124, del 18 de agosto de 2015, en un proceso de impugnación de paternidad y reclamación de paternidad, en que un Tribunal de Primera instancia acogió la demanda de filiación no matrimonial, invalidó el fallo impugnado, al considerar que la determinación de la filiación del niño de II años de edad, es una materia de especial importancia para sus intereses y en dicho proceso no se le escuchó, retrotrayendo el proceso a un estado previo a la audiencia preparatoria, a fin de garantizar al niño el derecho a ser escuchado, por haberse vulnerado el art. 12 CDN y el art. 16 de la Ley 19968/2004, creadora de los Tribunales de Familia, que establecen el interés superior del niño y su derecho a ser oído, como principios que los jueces de familia deben siempre considerar en los asuntos sometidos a su conocimiento (Espada Mallorquín, 2015). 
La Cámara de Apelaciones de Trelew, Chubut, en Argentina se dictó un fallo sobre medidas de protección vinculadas al Expediente No. 145 - Año 2015 CAT, de gran relevancia para el sistema de justicia en ese país, por el que se revocó una decisión de primera instancia que ordenaba a una adolescente concretar encuentros con su madre y un gradual retorno a su hogar, reafirmando el tribunal de segunda instancia la vulneración del derecho a ser oída, al no justificar en qué se apoyó la decisión, contraria a la opinión de la adolescente, porque no se valoró la prueba recabada por las profesionales del equipo interdisciplinar, cuyo informe reveló haber observado a la adolescente; madura, serena y consciente de su situación y dicha decisión la ha forzado a atravesar por situaciones para las cuales tal vez no esté aún preparada o no esté preparada su madre (Centro de Información Judicial. Agencia de Noticias del Poder Judicial, 27 de agosto 2015. Argentina).

La Sentencia 4I3/20I4, dictada el 20 de octubre de 20I4, por la Sala Primera de lo Civil del Tribunal Supremo de Madrid, España, declaró de oficio la nulidad de la sentencia recurrida, de 27 de marzo de 2013, de la Sección primera de la Audiencia Provincial de Orense, que revocó la sentencia de primera instancia que estimaba la modificación de un régimen de guarda y custodia, al otorgársela de forma compartida a favor de ambos progenitores. El Tribunal Supremo consideró; que debió escucharse al niño mayor de 12 años, lo que tuvo que evacuarse aún de oficio, por lo que se declaró la nulidad alegada y dispuso la retroacción de las actuaciones al momento anterior al dictado de la sentencia de primera instancia para que antes de resolver sobre la guarda y custodia, se oyera a los menores de edad de forma adecuada a su situación y a su desarrollo evolutivo, cuidando de preservar su intimidad y de solicitarse la audiencia por el niño, niña $o$ adolescente y se deniegue, tal decisión debe ser motivada (lustel, 20I5).

El TEDH en el Asunto Iglesias Casarrubios y Cantalapiedra Iglesias c. España, por Sentencia del 20 de septiembre de 2016, estimó con lugar la demanda, condenando al Estado español por vulneración del art. 6 del CEDH, relativo al derecho a un proceso equitativo, ordenando además al pago de gastos, costas y daños morales, al sostener el TEDH que habiéndose solicitado expresamente la escucha directa de una adolescente de más de 14 años y una niña de más de II años, la primera instancia ni la Sala de Audiencia Provincial, admitieron ni denegaron en forma alguna y motivada, las razones por las que no se escuchó a la hija menor de 12 años, siendo escuchada la hija mayor por el equipo psicosocial y con base en informes psicosociales anteriores, relativos al procedimiento de separación, para examinar la opinión de la hija menor de la demandante, sin oírlas personalmente o directamente por el Juez que debía resolver sobre el régimen de visitas de su padre, concluyendo el TEDH que se ha privado indebidamente a la recurrente del derecho de que sus hijas sean oídas personalmente por el juez, sin que las jurisdicciones superiores que examinaron los recursos interpuestos pusieran remedio a tal privación.

b. La opinión del niño ha de ser considerada atendiendo a su edad y madurez y no en atención a una edad determinada

En Argentina, la Sala I de la Cámara Nacional de Apelaciones en lo Civil, por Sentencia del 4 de marzo de 2009, con voto de mayoría confirmó el fallo de primera instancia, en el que se tuvo como parte procesal a dos hermanos de 15 y 12 años, que se habían presentado con patrocinio letrado en el proceso en que se debatía su tenencia [cuido y crianza], por cuanto ya eran parte procesal, dada la representación de sus progenitores, apartándose el Tribunal del rango etario de 14 años, para el ejercicio de determinados actos jurídicos, a fin de posibilitar la intervención de ambos hermanos en el proceso en calidad de parte procesal, postura que amparó el Tribunal de segunda instancia en el interés superior del niño y en la comunidad de intereses ostensible entre los hermanos, dejando sentado el reconocimiento del derecho de los impúberes de ser parte procesal, en consonancia con su edad y madurez contenida en el art. 12 CDN (Famá, 2009). 
Asimismo, la Corte IDH, en el asunto Furlan y Familiares vs. Argentina, por Sentencia de 3 I de agosto de 2012, reitera la progresividad del ejercicio de los derechos del niño atendiendo al desarrollo de su autonomía personal, al sostener que tanto en el ámbito administrativo como en el judicial se "deberá tomar en consideración las condiciones específicas del menor de edad y su interés superior para acordar la participación de éste, en la determinación de sus derechos", debiendo además de escuchar al niño o niños, tomar en cuenta su opinión de acuerdo con su edad y madurez, cuya opinión debe evaluarse caso por caso (Cuaderno de Jurisprudencia No. 5 , Corte IDH, s.f., 20).

\section{Relación entre el derecho del niño a ser escuchado e interés superior del niño, niña o adolescente}

Escuchar al niño, niña o adolecente en el proceso judicial o administrativo es fundamental para la determinación de su interés superior. Conocer su opinión en el procedimiento cuyos derechos e intereses afecta, atendiendo al grado de desarrollo físico e intelectual de éste, tiene por finalidad lograr la protección efectiva de su interés superior, tal como lo ha dejado sentado la OC 17/2002, Opinión Consultiva del Comité de los Derechos del Niño, sobre la Condición Jurídica y Derechos Humanos del Niño. (Cuadernillo de Jurisprudencia No. 5, Corte IDH, s.f., 6I).

En tal sentido, la Observación General No. 14 (2013) del Comité de los derechos del niño, relativa al interés superior de éste, ofrece una serie de elementos a tener en cuenta para la evaluación y determinación de su interés superior. Entre los elementos a considerar para su evaluación señala; la opinión del niño de acuerdo con su edad y madurez y como contrapartida invoca la necesidad de establecer la garantía procesal de escucharlo, a fin de que el referido interés superior se observe y el art. $12 \mathrm{CDN}$, reserva a los Estados desarrollar en su legislación interna, la forma y modalidades en que habrá de garantizar tal derecho, lo que conllevará a contar con un elemento de vital importancia, entre otros necesarios, para que la autoridad evalúe y determine el contenido de su interés superior en el caso, sin que sea posible darle contenido a dicho principio sin escuchar los deseos, sentimientos y necesidades del niño, en el caso concreto.

En el Asunto Atala Riffo e hijas vs. Chile, por Resolución de la Corte IDH de 29 de noviembre de 201 I, amparada en los arts. 8. I. de la Convención Americana de Derechos Humanos, art. 12 CDN y en la Observación General Número 12 (2009) del Comité de los Derechos del niño, relativos al derecho de éste a ser escuchado en el proceso, siendo que el dictamen sobre salud mental practicado a las tres niñas reporta una percepción de exclusión de éstas en el proceso de Tuición, lo que les ha generado ambivalencia debido a la confrontación entre sus progenitores y la posible contraposición de intereses entre aquellas y estos. Considerando el alcance de los derechos de las niñas de participar y ser oídas, el ejercicio de derechos de forma progresiva en la medida en que van adquiriendo mayor autonomía personal y que atendiendo a la edad de éstas, pueden ejercer directamente tal derecho, sin necesidad de representante, a menos que ellas así lo manifiesten, como diligencia para mejor resolver, la citada Corte IDH dispuso informarlas sobre su derecho a ser oídas ante la Corte y sobre las consecuencias que el ejercicio de tal derecho implica, a fin de que la preadolescente y las dos adolescentes expresaran sus deseos en dicho proceso, orientando considerar en la audiencia; el distinto desarrollo físico e intelectual, debido la diferencia etaria de las niñas, lo que podría generar opiniones diferentes.

Siguiendo dicha postura la Corte IDH en este mismo asunto, por Sentencia de Fondo, Reparaciones y Costas, recaída el 24 de febrero de 2012, invocando la referida Observación General Número 12 (2009) del Comité, recalcó la relación entre el interés superior del niño y el derecho a ser escuchado, sosteniendo que no puede aplicarse aquel, sin escuchar al niño en los términos establecidos en el art. I 2 CDN, ya que la funcionalidad del derecho de escucha está determinada por el interés superior del niño, concluyendo la Corte IDH, que la Corte Suprema 
de Justicia de Chile violó el derecho de las niñas a ser oídas y ser debidamente tomadas en cuenta, porque éstas expresaron su preferencia de vivir con su madre, pero aquella no explicó cómo evaluó y determinó el interés superior de las niñas, no dio las razones por las que se apartaron de la opinión de éstas, limitándose a invocar su interés superior, sin motivar o fundamentar las razones de legitimidad de su decisión (Cuadernillo de Jurisprudencia No. 5 , Corte IDH, s.f., 33). En sentido similar también se ha pronunciado la Corte IDH, en el asunto Furlan y Familiares vs. Argentina, por Sentencia de 3I de agosto de 20I2, como se cita líneas atrás, respecto del derecho de la participación del niño en el proceso para la determinación de su interés superior.

La jurisprudencia citada usa indistintamente los verbos oír, escuchar, opinar, lo que también hace la doctrina citada de distintas latitudes, así lo corrobora el magistrado Argentino Antonio Andrade, en un estudio sobre procesos de adopción al referir que: "Oír implica escuchar atentamente para conocer, $y$ de esta manera comprender $y / o$ entender, penetrar lo más posible en su interior" [del niño, niña o adolescente] (Andrade, 20I2, p.5), sin embargo; legislativa y doctrinariamente se ha asimilado el derecho de ser oído, al derecho de ser parte activa o pasiva en un proceso, por ello suscribimos la terminología empleada por el art. 12 de la CDN por ser a mi juicio más específica, es decir; el derecho a ser escuchado.

Como se ha venido remarcando, tanto la doctrina estudiada, como la jurisprudencia, en distintas latitudes geográficas, niveles jerárquicos de los tribunales y en un espacio temporal comprendido entre 2009 a 2016, ha sido unívoca, con algunas leves diferencias de un país a otro, en el sentido de que al niño, niña o adolescente se le debe escuchar, sin sujetarse a un rango etario y su opinión debe ser considerada por el órgano decisor, tanto en el proceso administrativo como en el judicial, pero el derecho a ser escuchado, de acuerdo con el art. 12 CDN y las legislaciones nacionales tiene tres cauces a seguir: a) a través de sus representantes progenitores 0 representantes designados por ley, llámese Ministerio Público, guardador o curador ad litem, b) a través de la escucha por los equipos interdisciplinares, asesores de la autoridad decisora y c) a través de la participación directa del niño, niña o adolescente ante la autoridad, de acuerdo a su edad y madurez según la legislación interna respectiva y con asistencia jurídica. Siendo ésta última en la que se centra el presente estudio y es la vía por la que la jurisprudencia se inclina cuando ha sido expresamente solicitada por los representantes o por el niño, niña o adolescente, al grado de declarar la nulidad de lo actuado cuando no se ha observado tal derecho, el que a su vez constituye una garantía procesal a la luz de la Observación General No. 12 (2009) y fundamental para la evaluación y determinación de su interés superior, como lo contempla la Observación General No. 14 (2013).

Se puede concluir que el derecho del niño, niña y adolescente a ser escuchado y que su opinión sea tenida en consideración por la autoridad judicial, parte de reconocer que éste es un sujeto de derechos, de reconocer el principio de autonomía progresiva de éste, ambos contenidos en los arts. 5 y 12 CDN, que la autonomía progresiva está estrechamente vinculada al desarrollo evolutivo del niño y atendiendo al grado de desarrollo físico e intelectual que va adquiriendo es que su opinión será tenida en consideración en mayor o menor medida y como una forma de reconocimiento de esos mayores niveles de desarrollo evolutivo y madurez es que a nivel legislativo, como se acoge en el Código Civil y Comercial de Argentina, se ha reconocido capacidad de ejercicio de ciertos derechos a los adolescentes a partir de los 13 años, sin que ésta edad constituya un parámetro rígido, como para considerar capaces a los que han alcanzado esta edad e incapaces a lo que no la han alcanzado, porque además de dicha edad ha de considerarse su madurez. Lo relevante aquí es que recocerles capacidad de ejercicio, implica que puedan constituirse como parte procesal para ejercer ciertos derechos previstos por la ley, sin la representación de sus progenitores o del Ministerio Público, pero poder expresar su opinión en el proceso cuyos derechos afecta no es excluyente de la representación de sus progenitores, como tampoco se requiere de un reconocimiento legislativo de capacidad de ejercicio o capacidad progresiva para opinar, para ser escuchado sobre la cuestión que le concierne. 
Para garantizar la efectiva participación del niño, niña o adolescente en el procedimiento cuyos intereses afecta, la introducción del abogado del niño en la legislación Argentina, constituye una novedad innovadora y garantista de los derechos de la niñez y la adolescencia en su calidad de sujetos de derecho, por representar aquel los intereses de éstos y no los de sus progenitores, a diferencia del Ministerio Público que en defecto de los progenitores, asume el rol de sustituto, mientras se le designa tutor, como lo regulan los demás países del cono sur de forma muy similar a la regulación nicaragüense.

\section{El derecho del niño, niña y adolescente a ser escuchado en el ordenamiento jurídico familiar nicaragüense}

Un hito para la democratización de las relaciones familiares y del reconocimiento de los derechos de la niñez y la adolescencia en Nicaragua, lo constituyó el Decreto 1065//982, Ley reguladora de las relaciones entre madre, padre e hijos, cuyo propósito fue eliminar el trato discriminatorio y desigual impuesto a la mujer en relación a los hombres, a fin de garantizar la igual participación de ambos progenitores en la dirección, conducción y representación de los hijos e hijas, como se infiere de su preámbulo y expresamente en su art. 14, que impone a las autoridades el deber de velar porque no se vulneren los derechos de la niñez contenidos en la Declaración Universal de Derechos del Niño, sin embargo niños y niñas, a la luz de la citada norma continúan siendo objetos de protección y no sujetos de derechos, quienes deciden lo que conviene o no al hijo o hija son sus progenitores, aquel no opina, aún no tiene derecho a la palabra, pero en definitiva constituye un avance, por cuanto ya no será únicamente el padre quien tomará las decisiones y representará los intereses relativos a la persona de su hijo, sino ambos progenitores y dicho Decreto marca el primer paso legislativo en ese momento histórico para el futuro reconocimiento pleno de los derechos de mujeres y niñez en el derecho nicaragüense.

La Constitución Política de Nicaragua (1987), en virtud de la reforma constitucional producida por la ley 192/1995 acogió la CDN, elevándola a nivel constitucional y por ende dándole el carácter de norma suprema, criterio sentado por Sentencias 57 y 78, de la Sala Constitucional de la Corte Suprema de Justicia, ambas del año 2010, en virtud de que los tratados no citados en los arts. 46 y $7 \mathrm{I} \mathrm{Cn}$, tienen un nivel infra constitucional (Cárdenas Velásquez, 20I I).

En tal contexto, ese catálogo internacional de derechos humanos de la niñez y la adolescencia es de observancia obligatoria por todos en general, hecho que derivó en la aprobación de la Ley 287/1998, Código de la Niñez y la adolescencia, en lo sucesivo CNA, conteniendo las normas de desarrollo ordinario de tan importante instrumento internacional.

El art. 17 CNA acoge el contenido del art. 12 CDN en lo que hace al derecho a ser escuchado, al expresar que:

Las niñas, niños y adolescentes tienen derecho a ser escuchados en todo procedimiento judicial o administrativo, que afecte sus derechos, libertades y garantías, ya sea personalmente, por medio de un representante legal o de la autoridad competente, en consonancia con las normas de procedimiento correspondientes según sea el caso y en función de la edad y madurez. La inobservancia del presente derecho causará nulidad absoluta de todo lo actuado en ambos procedimientos.

Luego de la adopción de todo el cuerpo normativo regulador y protector de los derechos de la niñez y la adolescencia a nivel interno, contenido en el CNA, el art. 448 CFN, acoge este derecho como un principio rector del proceso familiar al establecer que: 
Los niños, niñas y adolescentes que se encuentren bajo la autoridad parental deberán ser escuchados en todo procedimiento administrativo y judicial que tenga relación con ellos de manera personal $y$ en consonancia con las normas y procedimientos correspondientes, según sea el caso y en función de su edad y madurez. En caso de niños y niñas, la escucha será obligatoria cuando sean mayores de siete años.

Se advierte en la norma citada una antinomia, en el sentido de que limita el derecho a ser escuchado al niño, niña y adolescente que se encuentre bajo la autoridad parental, cabría preguntarse entonces; ipor qué el legislador no contempló a los que no se encuentren bajo la autoridad parental, por ejemplo; quienes se encuentran sujetos a tutela o candidatos a adopción aún no declaradas judicialmente, o se trata de un yerro en la técnica legislativa? También se infiere de la norma citada que la materialización de la escucha del niño, niña o adolecente debe practicarse atendiendo ciertas normas, pero las normas sobre el cómo escucharlo no existen a nivel administrativo ni judicialmente, por consiguiente nos encontramos con una laguna normativa.

Otro criterio al que se condiciona la escucha es; la edad y madurez, pero ¿cómo valorar la madurez del niño, niña o adolescente si no se le escucha? Finalmente el artículo citado establece los siete años de edad como parámetro etario en el que la escucha de éstos será obligatoria, lo que implicaría que los otros dos criterios ceden paso a este último, rango etario taxativo, que nos lleva a concluir con una interpretación a contrario, que los menores de siete años no será obligatorio escucharlos, entonces ¿cómo garantizar su derecho a ser escuchados? o ¿será que el legislador implícitamente estará atribuyendo tal derecho por vía de representación a sus progenitores, por cuanto la norma está diseñada para quienes se encuentran sujetos a la autoridad parental?

Dados los problemas interpretativos de orden sistémico y funcional, que generan las normas citadas, éstas habrán de resolverse a partir de criterios interpretativos jerárquicos e incluso de especialidad normativa, así que el art. 448 CFN cabe interpretarlo a la luz del art. 17 CNA, art. 7I Cn y art. I 2 CDN, entendiendo que el derecho a ser escuchado corresponde al niño, niña o adolescente en general, en el proceso de familia, sobre aquellos asuntos que le afecten personalmente, estén o no sujetos a la autoridad parental o lo que la doctrina denomina hoy día como responsabilidad parental. Las remisiones normativas inexistentes a las que se ha hecho referencia se podrían resolver con una interpretación a contrario, lo que no está prohibido está permitido, es decir; que no existiendo un procedimiento para la escucha del niño, niña o adolescente, nada impide que se establezca el procedimiento dentro de los límites que el ordenamiento jurídico permite, porque ante tal vacío, es donde la discrecionalidad del juzgador cobra relevancia, máxime que en el ordenamiento jurídico nicaragüense la autoridad judicial está obligada a resolver sin poder alegar inexistencia normativa, todo a fin de mantener coherencia en el sistema normativo, tal como lo proponen Gascón Abellán y García Figueroa (20 I3).

\section{I. Necesidad de escuchar al niño, niña y adolescente}

La CDN en su art. 12 establece el derecho del niño, niña o adolescente a ser escuchado y no solo escuchado sino que su opinión sea tomada en cuenta por las autoridades, cuyo instrumento internacional es vinculante para el Estado de Nicaragua, con jerarquía constitucional, con desarrollo normativo interno contenido en el CNA, en su art. 17, ya citado, establece como causal de nulidad absoluta del procedimiento la inobservancia de tal derecho, por ser un deber ineludible de las autoridades escucharlo, cuando sus derechos se ven afectados en un procedimiento administrativo o judicial, no es potestativo de las autoridades.

Nos interrogamos entonces ¿por qué ese imperativo de escuchar al niño, niña o adolescente? La CDN acoge la doctrina de protección integral que reconoce a la niñez y la adolescencia como 
sujetos de derechos y no como objetos de protección, como lo concebía la doctrina de la situación irregular, tal como lo plantea O'Donnell (2004) y siendo sujetos de derechos, les asiste el derecho de ser escuchados en la situación concreta que les afecta.

El ordenamiento jurídico procesal familiar nicaragüense, en su art. 448 CFN, establece el deber judicial y administrativo de escuchar al niño, niña o adolescente y con carácter obligatorio a partir de los siete años de edad. Con las falencias que pudiese tener este artículo, por interpretación jerárquica, se ha dicho en párrafos anteriores que se les debe escuchar en todo procedimiento que les afecte, no según el caso y según su edad, ya que se sabrá de su madurez escuchándolo y no precisamente por su edad. Pero no basta con escucharlo, es deber de las autoridades tomar en cuenta su opinión, como lo ordena el art. 12 CDN y será a partir de la situación concreta, que se deberá valorar su opinión, relativa a sus sentimientos, sus deseos y sus necesidades, las que deberá considerar la autoridad judicial a la luz de los hechos acreditados en el proceso y los derechos que le asisten, debiendo la autoridad judicial valorar los hechos, ponderar sus derechos y los derechos de otros niños, niñas o adolescentes, cuyos intereses también se encuentren comprometidos en dicha causa, a fin de que la decisión que se adopte, responda a las necesidades de éste y tutelar así su interés superior, sin vulnerar los derechos de otros niños, niñas y adolescentes en juego.

\subsection{Instrumentos legales para la materialización del derecho a ser escuchado}

A fin de determinar qué es lo que más conviene al niño, niña o adolescente, es necesario conocer los hechos que involucran el caso concreto, pero si tales hechos implican la toma de una decisión de autoridad que afecte a aquel, se debe conocer qué piensa al respecto, porque dicha decisión le afecta, le atañe y no se ha de tomar tal decisión de forma inconsulta, desde la óptica de los adultos, de quienes depende por razón de edad, por su falta de autonomía.

El derecho positivo nicaragüense ha instrumentado distintos mecanismos a fin de materializar el derecho del niño, niña o adolescente a ser escuchado y en tal sentido el art. 23 CFN reconoce a éstos como sujetos de derecho, con capacidad de ejercer derechos y contraer obligaciones, sin embargo, por razón de la edad y de su falta de madurez, de su dependencia de las personas adultas, se les limita la capacidad de ejercicio de sus derechos, los que habrán de ser ejercidos a través de sus representantes, es decir; de sus progenitores, de sus tutores o de las instituciones que por ley deban de ejercer su representación. La limitación a la capacidad de ejercicio de sus derechos, no impide el derecho de poder intervenir, expresar libremente sus consideraciones, de ser escuchado sobre sus opiniones y otros derechos fundamentales, de ahí el deber impuesto por el art. 448 CFN, art. 17 CNA y art. 12 CDN de escuchar y tener en cuenta la opinión de éste en todas aquellas decisiones que le afectan.

En el Código de Familia (20l4), se encuentran distintos mecanismos para materializar la escucha del niño, niña y adolescente, los que enseguida abordamos.

a) Entrevista judicial directa

El art. 17 CNA, establece que se debe escuchar al niño, niña o adolescente personalmente, por medio de un representante legal o de la autoridad competente y nos remite a realizar tal deber, de conformidad con las normas de procedimiento correspondientes, bajo pena de nulidad del procedimiento si no se le escucha. El art. 448 CFN, ya citado, impone a las autoridades administrativas y judiciales el deber de escucharlo, sobre aquellos asuntos que les afecten de manera personal y se le deberá escuchar en consonancia con las normas y procedimientos correspondientes. El art. 484.j, del mismo cuerpo normativo citado, establece que es un deber de la autoridad judicial oír al niño, niña y adolescente, pudiendo tener contacto y un diálogo con 
éste, habiendo oído el parecer del especialista miembro del Consejo técnico asesor, de lo que se deduce que no en todos los casos la autoridad judicial habrá de escucharlo directamente.

También ha de considerarse que el niño, niña y adolescente cuyos intereses se debaten en la toma de decisiones, puede tener limitaciones por razones de discapacidad intelectual y es lo que prevé el art. 3I del mismo Código, a fin de declarar su incapacidad. En tal sentido se dispone ya no solamente la obligación de escuchar, sino de observar, de "examinar" dice la norma, al presunto incapaz, lo que implica que el derecho a la escucha no solo incluye el lenguaje verbal, sino también el lenguaje corporal con que pueda manifestarse aquel, a fin de que la autoridad judicial habiéndolo escuchado u observado con el auxilio del Consejo técnico asesor, hechos los dictámenes médicos pertinentes, determinantes del grado de incapacidad y demás medios probatorios, pueda formarse un juicio para la decisión a adoptar.

De las normas precitadas se infiere, que la autoridad judicial escuchará directamente al niño, niña y adolescente, es decir de forma personal, aunque el legislador usa el verbo oír y el verbo escuchar, hemos de asumirlos como sinónimos, lo que también hace la legislación comparada y la doctrina (Pellegrini, 2008; De Carlo, 2014; Salum Alvarado, Salum Alvarado y Saavedra Alvarado, 2015; Kemelmajer de Carlucci, A. y Pérez Gallardo, 2006). La Entrevista Judicial directa, constituye una actuación de autoridad para garantizar el derecho a ser escuchado, que se debe observar de forma obligatoria a partir de los siete años de edad, además de otras formas de escucha, que adelante referiremos; sin embargo, las normas citadas, ni la norma supranacional contenida en el art. $12 \mathrm{CDN}$, nos permiten desentrañar el procedimiento concreto a seguir para la materialización del derecho a ser escuchado, por falta de desarrollo normativo procesal del derecho positivo. Así que; haciendo una interpretación jerárquica e integradora de dichas normas, queda a discrecionalidad del juzgador decidir la forma en que llevará a cabo tal cometido, la que puede ser directa ante la autoridad decisora, de carácter obligatorio, en forma de diálogo u observación en su caso, para conocer de los sentimientos, deseos y necesidades del niño, niña o adolescente, relativas a sus derechos, como un elemento a considerar para la evaluación y determinación de su superior interés, cuya finalidad se desprende del citado art. 12 CDN y es la de tener en cuenta las opiniones de éste sobre el asunto que le atañe, todo a la luz de la Observaciones Generales No. 12/2009 y No. 14/2013.

\section{b) Estudio psicosocial}

Escuchar al niño, niña o adolescente, a través de de un órgano apropiado, en consonancia con las normas de procedimiento de la ley nacional, es otra modalidad de escucha que contiene el art. I2.2 CDN.

La legislación familiar nicaragüense no expresa categóricamente cuál ha de ser el órgano apropiado, a través del cual se haya de escuchar al niño, niña o adolescente, en el procedimiento administrativo o judicial, sin embargo del conjunto normativo familiar se deduce que es el consejo técnico asesor, regulado en el art. 489 CFN, el encargado de hacerlo. La citada norma establece que una de las funciones de éste es la de realizar los estudios y dictámenes a requerimiento judicial, a fin de procurar la protección del niño, niña o adolescente y además debe asesorar a la autoridad judicial para la adecuada comparecencia y declaración de éste.

Otra pregunta que surge es: si el art. I 2 CDN contempla también la posibilidad de escuchar al niño, niña o adolescente a través de un órgano apropiado y ello se satisface con un estudio social o un dictamen psicológico o médico, ies necesario que la autoridad judicial directamente lo escuche, quien ha sido abordado ya, por los especialistas del consejo técnico asesor? La respuesta es que no. El art. 483.g CFN, faculta a la autoridad judicial a evitar actuaciones que impliquen re victimización e instrumentalización de niños, niñas y adolescentes en el proceso, sus múltiples comparecencias ante el consejo técnico asesor y luego ante la autoridad judicial 
puede ser contraproducente, una forma de revictimizarlo, al tener que relatar una y otra vez la situación familiar que enfrenta, sin embargo; tales pericias han de ser valoradas por la autoridad judicial junto con el resto del caudal probatorio, no de forma aislada, deberá ponderar los intereses en juego en el caso concreto y es sobre el conjunto probatorio, lo vertido por el niño, niña o adolescente y la norma jurídica aplicable, que la autoridad adoptará la decisión a tomar de forma motivada y fundamentada, no acogiendo sin mayores consideraciones lo informado por el equipo técnico asesor, como lo ha puesto de manifiesto un estudio sobre la situación de niños y niñas ante la administración de justicia en España, según Rodríguez, Román y Escorial (2012).

En las regulaciones normativas de algunas acciones procesales específicas, se contempla la intervención del consejo técnico asesor, como en la declaratoria judicial de mayoría de edad, contenida en el art. 304 CFN que prevé requerir informe a dicho órgano con finalidad probatoria, sobre las aptitudes físicas, intelectuales, morales y capacidad de auto sostenimiento para entrar en el goce de la mayoría de edad. De los requerimientos judiciales del informe se colegirá, que al menos un profesional de la psicología, un trabajador social o un médico, habrán de intervenir en dicho estudio, para lo cual deberán entrevistar al adolescente, cuyo informe y deposición del especialista en juicio, según el art. 528 CFN, junto a otros medios probatorios que se aporten al proceso valorará la autoridad judicial para tomar la decisión que estime ajustada a derecho, relativa a la declaratoria de mayor edad.

\section{c) Representación legal}

El ordenamiento jurídico familiar también prevé como mecanismo para la escucha del niño, niña o adolescente, la representación de sus progenitores o a través de la Procuraduría Nacional de Familia, en las situaciones que a continuación se abordan.

\section{c.I. Representación por los progenitores o tutores}

El art. I2.I CDN contempla la posibilidad de escuchar al niño, niña o adolescente a través de sus representantes, es decir; a través de sus progenitores y así lo acoge también el art. 17 CNA, representación legal que de acuerdo con el art. 270 CFN, será ejercida por el padre y la madre conjuntamente o por uno de ellos cuando falte el otro, por haber fallecido, por encontrarse ausente o fuere declarado judicialmente incapaz, o por quien tuviere la representación declarada judicialmente, como es el caso del tutor o tutora, a falta de ambos progenitores por las causas antes citadas o por habérseles suspendido o privado de la autoridad parental, judicialmente, conforme los arts. 294 y 295 de la citada codificación familiar.

Si bien la CDN contempla también la posibilidad de escuchar al niño, niña o adolescente a través de representantes como se ha dicho en el párrafo anterior, opción que también acoge el art. 17 CNA; sin embargo, el art. 448 del CFN impone el deber de escuchar al niño, niña o adolescente, en todo procedimiento que tenga relación con éste de manera personal. Como se aprecia, la norma ordinaria familiar privilegia la escucha personal de éste y no a sus representantes, al establecer el deber de escucharlo en el procedimiento administrativo o judicial con el que esté relacionado, cuyo deber el citado art. 448 lo hace depender de dos condiciones, redacción que considero inapropiada. Se establece primero, un mandato de carácter general, que luego condiciona a; la naturaleza del caso que se ventila y la edad y madurez de aquel, para finalmente cerrar con una contradicción al disponer la escucha obligatoria del niño, niña o adolescente a partir de los siete años. Pese a ello, se privilegia la escucha personal y no a través de sus representantes, independientemente del consenso que pudiese existir entre los progenitores, lo que esta autora se explica bajo la premisa de que no puede dejarse por sentando que las pretensiones de los progenitores coincidan con los intereses y derechos del niño, niña 0 adolescente, hijo en común, o con los del tutor, en su caso. Se hace necesario escucharlo para corroborar el consenso con sus progenitores sobre el asunto relacionado al hijo o hija, o para 
corroborar la contraposición de intereses entre éstos respecto de los derechos de aquel, o la oposición de ambos progenitores o del tutor frente al niño, niña o adolescente, cuya postura encuentra su asidero en la disposición 273 CFN, que veda la representación de los progenitores en aquellos actos relativos a los derechos de la personalidad y otros que de acuerdo a la ley y su edad, pueda realizar por sí mismo, tal es el caso del derecho de expresar su opinión sobre el procedimiento al que se encuentra vinculado, en la forma que se ha descrito anteriormente.

Los derechos de la personalidad Bustos Pueche (1997) los caracteriza como innatos u originarios, los define como una:

...categoría especial de derechos subjetivos que, garantizan el goce y respeto de su propia entidad e integridad, en todas sus manifestaciones espirituales y físicas. Garantizan el goce de nosotros mismos, el señorío sobre la persona, la actualización de las propias fuerzas físicas o espirituales. Son los derechos supremos del hombre que le aseguran el disfrute de sus bienes más personales e íntimos. (p.43)

De Espanés e Hiruela de Fernández (s.f.), sobre tales derechos, en similar sentido expresan que: “...son aquellos que 'corresponden innatamente a toda persona, desde antes de su nacimiento y hasta su muerte, y que le garantizan el íntegro ejercicio y desenvolvimiento de sus atributos esenciales para así poder desarrollarse plenamente en su humanidad'” (p.2). Los autores citados sostienen que la posición doctrinaria de mayoría sobre la naturaleza jurídica de tales derechos, es que son verdaderos derechos subjetivos tutelables, compuestos por un sujeto titular, un objeto y un contenido, cuyo sujeto pasivo es toda la comunidad y son derechos que se deben respetar, tales como: el derecho a la integridad física; que comprende todas las manifestaciones de la persona sobre su propio cuerpo, el derecho a la libertad; de movimiento, de hacer o no hacer y de expresarse, el derecho a la libertad espiritual; es decir, el derecho al honor, a la propia imagen, a la intimidad y a la vida privada y el derecho al reconocimiento y respeto de la propia individualidad; que comprende el derecho al nombre, que constituye un derecho personalísimo $y$ un atributo de la persona.

A la luz de la regulación positiva y las conceptualizaciones doctrinarias referidas, se infiere que la intención de legislador nicaragüense ha sido garantizar el derecho del niño, niña o adolescente de ejercer sus derechos de forma personal, sobre todos aquellos asuntos inherentes, a su condición de persona humana, sin intermediación de otras personas, incluyendo a sus progenitores, es decir sus derechos personalísimos, que incluyen el derecho a expresarse, a opinar personalmente sobre el asunto que le atañe. En palabras de Pellegrini (2008), ejerciendo su defensa material, así que escuchándolo es que la autoridad decisora conocerá su opinión y sabrá si los intereses de sus progenitores son coincidentes o se contraponen entre sí o conjuntamente frente a los intereses del niño, niña o adolescente, cuyo derecho de la personalidad a su vez constituye un derecho fundamental y una garantía procesal de trascendental importancia para la tutela de sus derechos, tanto así que conforme el art. 17 CNA, se torna nulo el procedimiento por su inobservancia.

\section{c.2. Representación del Estado}

La Procuraduría Nacional de Familia en su calidad de órgano estatal, es uno de los sujetos del proceso especial común familiar, al que le compete conocer, opinar y dictaminar en todos los asuntos de familia que sean sometidos a su conocimiento, la que intervendrá incluso como representante de los intereses del niño, niña o adolescente huérfano, de filiación desconocida o abandonado y de aquellos no sujetos a la autoridad parental o que carezcan de representación legal, hasta que se le provea de tutor, o encargados del cuidado de su persona y de la defensa de sus bienes y derechos. 
A falta de los progenitores, en circunstancias de contraposición de intereses de los progenitores entre sí, o de ambos frente al hijo, será entonces la Procuraduría Nacional de Familia la que representará los intereses del niño, niña $\circ$ adolescente, hasta que se le designe tutor, representante, o encargado de su cuido y crianza, todo lo cual se desprende de los arts. 5, 27I, 273 infine y 475 CFN, sin perjuicio del derecho personalísimo de aquel de ser escuchado en el proceso que le atañe, como lo ordena el art. 448 CFN, en consonancia con los arts. 17 CNA y 12 CDN. Pero éste no solo puede figurar en el proceso como sujeto activo sino como sujeto pasivo y careciendo de representante legal o si se ignorase su paradero, la Procuraduría Nacional de Familia, representará sus intereses, una vez comprobada tal circunstancia en audiencia especial, según el art. 477 CFN.

Las normas objeto de análisis llevan a concluir que la representación de los padres, tutores y del Estado, relativa a los derechos de los niños, niñas y adolescentes, se deriva de la limitada capacidad de ejercicio de derechos de éstos, para comparecer ante la administración pública y la administración de justicia, para la tutela de sus derechos, cuya representación no abarca el derecho personalísimo de ser escuchado, el cual habrá de ejercer por sí, directamente ante la autoridad judicial o ante el consejo técnico asesor, para expresar su opinión en el procedimiento cuyos derechos se ven concernidos, sin detrimento de la representación legal que deban ejercer sus progenitores, tutores o la Procuraduría Nacional de Familia y el Ministerio de la Familia en los casos previstos por la ley.

El derecho comparado marca la tendencia de no establecer rangos etarios para la escucha de niños, niñas y adolescentes, en lo que hace al derecho de opinar en el procedimiento, si no que a la luz de cada caso concreto se habrá de decidir tal participación, atendiendo a la edad y madurez o desarrollo evolutivo de éste y se reconoce tanto su autonomía progresiva, que valora la autoridad decisora, como también la capacidad progresiva, según su edad, por lo general, a los mayores de 13 ó 14 años, por disposición expresa de la ley, en Argentina y El Salvador respectivamente, para el ejercicio de determinados supuestos de derechos también expresados en la norma, cuya tendencia siguen la mayoría de los Códigos de Familia y Códigos de la Niñez de América Latina, cuestión que se desprende de los arts. I y 2 del Código de la Niñez y la Juventud de Guatemala (1996), los arts. 5, 12, 94 y 218 de la Ley de protección de la niñez y la adolescencia y art. 216 del Código de Familia, ambos de El Salvador, arts. 5 y 147.c, del Código de la niñez y la adolescencia y art. 246 del Código de Familia, ambos de Honduras, arts. 14, 34 y 105 del Código de la Niñez y la Adolescencia y art. 123 del Código de Familia, ambos de Costa Rica, arts. 2 y 24 de la Ley 2606I, de protección integral de los derechos de las niñas, niños y adolescentes y art. 26 del Código Civil y Comercial de la Nación (2014), ambos de Argentina y art. 36 del Código de las familias y del proceso familiar de Bolivia (2014).

\section{El derecho del niño, niña y adolescente a ser escuchado en la práctica jurisdiccional familiar nicaragüense}

En un estudio realizado por esta autora en el presente año 2017, relativo a el interés superior de la niñez y la adolescencia en el contexto jurídico nicaragüense, se analizaron 32 sentencias procedentes de 10 de las 14 Judicaturas de Familia, de primera instancia con sede en Managua, las que servirán para este estudio, por la estrecha vinculación del tema del derecho a ser escuchado y el interés superior del niño, niña o adolescente, cuyos criterios fueron considerados en su momento, para la búsqueda de dicho material jurisdiccional, sin embargo se ha dispuesto ampliar la muestra a otros departamentos, considerando la similitud temporal de creación de dichas judicaturas. Se ha ampliado la muestra a los departamentos de Matagalpa, Jinotepe y Bluefields, ubicados en distintas zonas geográficas, equidistantes u opuestas en Nicaragua.

El universo de la muestra comprende 43 sentencias, procedentes de 13 judicaturas; 10 de primera instancia, con sede en Managua y 3 de primera instancia con sede en; Matagalpa, Jinotepe y Bluefields, respectivamente y el Tribunal de Apelaciones de Managua, en su calidad de tribunal 
de segunda instancia con sede y competencia territorial en el departamento de Managua, las que fueron dictadas en los años 2016 y 2017 y corresponden a acciones en las que cobra especial relevancia el derecho del niño a ser escuchado, como son; II acciones relativas a la autoridad parental, 15 de cuido y crianza y 17 adopciones, cuyo estudio explora particularmente tres cuestiones, si se garantizó el derecho del niño, niña o adolescente a ser escuchado, las modalidades adoptadas para garantizar el derecho del niño, niña o adolescente a ser escuchado en cada una de las instancias y si se tomó en cuenta la opinión de éste en la decisión jurisdiccional, las que se sistematizaron documentalmente, considerando los criterios citados, que nos aporta la Observación General No. 12 (2009).

De las 43 sentencias objeto de revisión, en el $72 \%$ (3I) de ellas se garantizó el derecho del niño, niña o adolescente a ser escuchado, en tanto que en el 28 \% (I2) no se garantizó tal derecho, a 15 de ellos, lo que de acuerdo con la legislación nacional vigente, contenida en el art. 17 CNA, torna nulo el procedimiento por vulneración de tal garantía procesal, sin embargo no se infiere protesta alguna de las partes procesales por tales vulneraciones.

En las $3 \mathrm{I}$ causas en las que se garantizó al niño, niña o adolescente el derecho a ser escuchado, 6 correspondieron a acciones relativas a la responsabilidad parental, 8 a cuido y crianza y 17 adopciones; de las que en su totalidad se realizaron estudios bio sicosociales en el ámbito administrativo, en los que se basaron las autoridades judiciales para la adopción de sus decisiones.

El total de causas objeto de estudio, involucraron a 29 niños, niñas y adolescentes, de todos los rangos etarios que van desde los 10 meses hasta los 17 años de edad.

En 26 del total de causas, se realizaron estudios interdisciplinares, en 8 se realizó la entrevista judicial directa a niños, niñas y adolescentes por encima de los 9 años de edad, en tanto que se observó a I de 2 años de edad, a fin de constatar la relación o comportamiento del niño respecto de sus adoptantes, evidenciándose una tendencia marcada por escucharlos directamente cuando han superado los 7 años de edad, a que alude el art. 448 CFN. Por su parte, los estudios interdisciplinares se realizaron incluyendo a niños, niñas y adolescente de cualquier edad, de lo que se podría inferir la preferencia de las autoridades judiciales a derivar la escucha de éstos a los equipos interdisciplinares y no a la escucha judicial directa, aunque no se logra determinar el criterio considerado para disponer la escucha directa o indirecta. En 6 de los 8 casos citados, además de la entrevista directa, también se realizaron estudios interdisciplinares, a fin de conocer la situación real de los niños, niñas y adolescentes involucrados, en el contexto familiar, de cuidados dispensados y en los planos; afectivo, escolar y de salud física y emocional, es decir que se garantizó el derecho de ser escuchados a través de los equipos interdisciplinares y de forma directa por la autoridad judicial, lo cual podría ser contraproducente por la duplicidad de intervenciones.

En las 31 causas en las que se escuchó a los niños, niñas y adolescentes, lo cual se registra en las actas judiciales o en informes psicosociales, en su caso, a los que pueden acceder las pates procesales, las sentencias dan cuenta de la valoración de las opiniones vertidas y de la relación de éstas con los hechos llevados al proceso, en alguna medida, aunque en su mayoría solo se invoca la norma ordinaria sobre tal derecho, no así la norma supranacional, ni las Observaciones Generales del Comité de los Derechos del Niño, relativas al derecho a ser escuchado, ni al interés superior de éste, de las que se hace uso; solo en I de los casos objeto de estudio, una causa de Adopción, en la que se garantizó la intervención de una adolescente de 17 años con patrocinio letrado de la Defensoría Pública, quien compareció a la Audiencia Inicial, al igual que los demás sujetos procesales, asistida jurídicamente. Tal medida a mi juicio obedece al activismo judicial observado por el juez, ya que en el ordenamiento jurídico nicaragüense no existe la figura del abogado del niño, como lo regula el art. 27. c de la Ley 26061/06, de Protección Integral de los Derechos de Niñas, Niños y Adolescentes de Argentina y su desarrollo reglamentario contenido el art. 27 del Decreto 415/06, que ordena la implementación de los mecanismos 
respectivos para garantizar tales servicios jurídicos. Dicho activismo judicial no está reñido con el ordenamiento jurídico nicaragüense, porque al conferirle un estatus constitucional a la CDN desde el año 1995, no contando con el desarrollo legislativo ordinario en tal sentido, la norma convencional y constitucional son de aplicación directa y las Observaciones Generales No. 12/2009 y No. 14/2013, que emanan del Comité de los Derechos del Niño, constituyen recomendaciones a los Estados, de ahí la necesidad de adoptar las medidas necesarias tendentes a garantizar tal derecho de forma más o menos homogénea, a fin de materializar el derecho de éste a ser escuchado, atendiendo a su edad y madurez, es decir; a su autonomía progresiva, considerando su opinión, y una forma de posibilitar la participación activa del adolescente particularmente, es dotándolo de la asistencia jurídica apropiada para tal fin.

En las 12 causas en que no se garantizó el derecho de los niños, niñas y adolescentes a ser escuchados en el proceso, 3 son de suspensión de la autoridad parental, que a su vez involucraron a 2 niños, I niña y I adolescente, de 9, 10 y 13 años de edad, en tanto que solo I niña contaba con 6 años de edad. En 2 de dichas causas se concertaron acuerdos sobre derechos indisponibles, al acordarse la renuncia a la autoridad parental, que en I caso se acogió por sentencia judicial y en I caso no se admitió tal pretensión y se atribuyó el cuido y crianza a la abuela materna. Sobre pérdida de la autoridad parental se registran 2 casos, que involucraron a I adolescente mujer de 14 años y a 2 niños, de 1 I y 9 años, argumentándose en ambos casos; la circunstancia de desconocerse el domicilio del progenitor demandado e incumplimiento de la responsabilidad parental alimentaria y cuyos cuidados estaban a cargo de otros miembros de la familia extensa, abuelas, por encontrarse las progenitoras demandantes en el exterior, cuyas pretensiones fueron estimadas sin haber escuchado a la adolescente y niños afectados con tal decisión judicial, infiriéndose de ello que la finalidad de tales procedimientos tenían fines migratorios. En los 7 casos de cuido y crianza, afectaban a 8 niños, niñas y adolescentes, 3 casos del total, tenían fines migratorios e involucraban a 3 adolescentes; 2 mujeres y I hombre, de entre 13 y 17 años, en 2 casos se involucraban los intereses de $I$ niño y $I$ niña, de 3 años de edad respectivamente y en 2 de los casos se afectaban los intereses de 3 niños, niñas o adolescentes, cuyas edades no se lograron determinar en las sentencias analizadas.

Otro dato de interés, es que del total de 12 casos, en los que no se escuchó a los niños, niñas y adolescentes, en el $41.7 \%$ (5) de ellos, tenían finalidad migratoria, por encontrarse sus progenitoras en el exterior, debiendo recurrir a la privación de la autoridad parental o al cuido y crianza y representación legal exclusiva a favor de éstas, a fin de posibilitar la reunión familiar, quedando la incertidumbre en dichas resoluciones, sobre si el deseo del niño, niña o adolescente era coincidente con el de su representante progenitora, cuya duda hubiese quedado disipada si dichas sentencias dieran cuenta de los sentimientos, deseos y necesidades del niño, niña 0 adolescente expresadas por éste, aunque parezcan obvias, y no supuestas por sus representantes y acogidas por la autoridad decisora, quien debe dar cuenta de ello, no suponerlo, porque a estos niños, niñas y adolescentes también les asiste el derecho de mantener comunicación y contacto periódico con su otro progenitor aunque vivan en países diferentes, si tal relación le fuese beneficiosa, lo cual no se logró conocer por no habérseles garantizado el derecho a ser escuchados, de dar su opinión en el proceso y que ésta se tenga en cuenta.

Los hallazgos en las sentencias objeto de estudio, ponen de manifiesto la necesidad armonizar la actuación jurisdiccional, sobre el tiempo, modo y lugar en que ha de intervenir el niño, niña o adolescente en el procedimiento jurisdiccional y de las garantías que en el mismo se le deben ofrecer, a fin de que pueda disponer de la información del procedimiento que le atañe oportunamente, como también de los medios adecuados para participar de forma activa y eficaz en el proceso, ya sea para una escucha directa por la autoridad judicial con el apoyo de expertos, - con la asistencia jurídica debida, atendiendo a la autonomía progresiva y mayor capacidad de discernimiento que éste va adquiriendo en la medida que se desarrolla o habrá de escucharlo de forma indirecta, a través de los estudios que hayan de realizar los equipos interdisciplinares [equipo técnico asesor], a fin de que su derecho a ser escuchado sea eficaz. 
Lo anterior requiere de normas de procedimiento que pudiesen estar contenidas en un protocolo de actuaciones con niños, niñas y adolescentes en el proceso de familia, específicamente, tal como lo he sugerido en un estudio sobre "El interés superior de la niñez y la adolescencia en la justicia de familia nicaragüense" (Rivera Zamora, 2017), pudiendo tomar como referente el Protocolo de actuación para quienes imparten justicia en casos que afectan a niños, niñas y adolescentes de México (Suprema Corte de Justicia de la Nación, 2012) y el Protocolo iberoamericano de actuación judicial para mejorar el acceso a la justicia de personas con discapacidad, migrantes, niñas, niños, adolescentes, comunidades y pueblos indígenas (Suprema Corte de Justicia de la Nación, México, 20I4), que ha sido elaborado en el seno de la Cumbre Judicial Iberoamericana, cuya finalidad es la de propiciar la cooperación, la concertación y el intercambio de experiencias, de los Poderes Judiciales de la región lberoamericana a través de sus máximos representantes (http://www.cumbrejudicial.org), de la cual Nicaragua es miembro.

Sin perjuicio de ello y siendo que la CDN, además de ser un compromiso internacional del Estado de Nicaragua, por tener un nivel constitucional y que las observaciones generales del Comité de los Derechos del Niño deben ser cumplidas por los Estados, nada impide que las autoridades judiciales en materia de familia para garantizar el derecho de niños, niñas y adolescentes a ser escuchados puedan implementar las siguientes pautas mínimas para tal fin:

a) Sometidos al conocimiento jurisdiccional asuntos relativos a autoridad parental, cuido y crianza, filiatorios y adopciones, que involucren a niños, niñas y adolescentes, la autoridad judicial deberá garantizar su intervención directamente, con asistencia letrada de la Defensoría Pública para aquellos mayores de 12 años o con edad, madurez y desarrollo evolutivo suficiente, en circunstancias de inexistencia de los progenitores, contraposición de intereses de éstos entre sí o frente a aquel, de ser posible, a fin de que reciba orientación jurídica y acompañamiento para el ejercicio de su derecho a ser escuchado, disponiéndolo desde el auto de admisión de la demanda y emplazamiento, siguiendo así la tendencia de la mayoría de los países de Centro y Sur América, sin circunscribirla a rangos etarios específicos.

b) Sometidos al conocimiento jurisdiccional asuntos relativos a autoridad parental, cuido y crianza, filiatorios y adopciones, que involucren a niños y niñas menores de 12 años de edad, la autoridad judicial dispondrá su participación voluntaria, directamente en audiencia inicial, si el nivel de desarrollo evolutivo y madurez de éstos así lo aconseja, o escuchando su opinión, deseos, sentimientos y necesidades a través del equipo técnico asesor, cuyo informe deberá requerirse desde el auto de admisión de la demanda y emplazamiento, en su caso, para su conocimiento previo a la audiencia inicial.

c) La autoridad judicial dispondrá la comparecencia voluntaria de los niños, niñas y adolescentes mayores de 12 años de edad, a la audiencia inicial junto con su asesoría técnica jurídica, si así lo desean, a fin de brindar su opinión, sobre el asunto cuyos derechos afecta, si lo tienen a bien y disponiendo no hacerlo, así lo habrá de informar personalmente o a través del asesor designado.

d) En la intervención del equipo técnico asesor con niños, niñas o adolescentes habrá de considerarse la disposición de éstos de ser escuchados o no y respetar tal voluntad, sin perjuicio del debido cumplimiento de los demás requerimientos judiciales de dicha pericia, señalamientos y recomendaciones que estimen a bien, el que se valorará junto con los demás medios probatorios, ponderando los intereses en juego, cuyos hechos 
probados servirán de base para que la autoridad judicial arribe a su convicción, considerando los supuestos normativos y ejerciendo así su potestad jurisdiccional.

e) Evitar la revictimización del niño, niña o adolescente con las múltiples comparecencias en el proceso, como pudiera ser la asistencia ante la autoridad judicial y ante el equipo técnico asesor para la escucha, de forma innecesaria o reiterada.

f) La audiencia judicial en la que haya de intervenir un niño, niña o adolescente habrá de ser reservada, en la que debería estar presente también el asesor técnico de éste 0 un profesional de la psicología del equipo técnico asesor, la Procuraduría de Familia y el Ministerio de la Familia, no así la parte demandante y demandada, a fin de evitar un ambiente hostil y de confrontación del hijo o hija con uno u otro progenitor o respecto de ambos.

g) Procurar la intervención de psicólogos e intérpretes, para la comparecencia de niños, niñas y adolescentes, con alguna discapacidad física o intelectual, o traductores en caso de que no comprendan el idioma del Tribunal.

h) Las instalaciones físicas en las que se entrevistará al niño, niña o adolescente deberá prestar las condiciones apropiadas para escucharlo en un ambiente tranquilo y $\sin$ exponerlo a presiones de las partes procesales y al público.

i) La autoridad judicial velará porque los acuerdos que se concierten entre las partes, se considere la opinión del niño, niña o adolescente y las recomendaciones del equipo técnico asesor, si procediera, ejerciendo el control de legalidad respectivo.

j) La Procuraduría de Familia y el Ministerio de la Familia en su calidad de sujetos procesales deben intervenir materialmente en el procedimiento jurisdiccional familiar por ser preceptiva su intervención.

k) Toda decisión judicial provisional o definitiva que involucre los derechos de niños, niñas y adolescentes, deberá tomar en cuenta la opinión de éstos, la que deberá ser valorada junto con las alegaciones de las partes y medios de prueba que se aporten al proceso, debiendo considerar de todas las alternativas posibles en la decisión a tomar, aquella que mejor garantice los derechos de éstos y con ello su interés superior.

I) Los operadores jurídicos internos y externos y miembros de los equipos técnicos asesores del sistema de justicia de familia deben contar con capacitación periódica en materia de derechos humanos de la niñez y la adolescencia y sobre derecho de familia, sobre la vinculación de estos derechos con la actuación administrativa y jurisdiccional y las garantías que han de observar dichos procedimientos, a fin de tutelar efectivamente los derechos de los niños, niñas y adolescentes.

\section{Conclusiones}

I. El derecho del niño, niña y adolescente a ser escuchado en todo procedimiento administrativo y jurisdiccional está presente en la CDN y en el ordenamiento jurídico nicaragüense, al tener plena vigencia la CDN en Nicaragua desde el año 1990, en que se ratificó y nivel constitucional desde 1995 en que se dio la reforma constitucional por la ley 192, de reforma parcial a la Constitución Política de Nicaragua. 
2. El derecho del niño, niña o adolescente a ser escuchado es un imperativo convencional, constitucional y legal, al grado que el CNA establece la sanción de nulidad absoluta de las actuaciones administrativas y jurisdiccionales que no observen tal derecho.

3. Las antinomias que se presentan en las normas de desarrollo legislativo ordinario en los arts. 17 CNA y art. 448 CFN y el contenido normativo del art. 12 CDN, relativas al derecho del niño, niña o adolescente a ser escuchado, deben resolverse partiendo de una interpretación jerárquica del sistema normativo, por constituir éste un derecho que asiste a todos en general, en todo procedimiento administrativo y judicial cuyos derechos afecten y no solo para aquellos que están sujetos a autoridad parental.

4. La práctica jurisdiccional familiar, como se ha constatado es dispersa, en algunos casos hay reiteración de intervenciones con el niño, niña o adolescente, lo cual podría causar re victimización, en otros; no se logró conocer su opinión en el procedimiento cuyos derechos afectaba, tornando nulo absolutamente todo el procedimiento, no protestado por la parte contraria, ni por las instituciones públicas intervinientes y en los casos en los que se garantizó tal derecho, hay una marcada tendencia por la escucha indirecta, a través del equipo técnico asesor indistintamente de la edad y una escucha directa por la autoridad judicial a aquellos con edades superiores a los 7 años de edad.

5. En el $28 \%$ ( 12 ) de las sentencias judiciales analizadas, no se ha garantizado el derecho material de 15 niños, niñas o adolescentes a ser escuchados, sino a través de uno de sus representantes por lo general, indicador de contraposición de intereses respecto del otro progenitor, que por lo general será la parte contraria en el proceso judicial, por lo que no se llegaron a conocer realmente los deseos, sentimientos y necesidades de éstos, para la debida protección y tutela de sus derechos.

6. El total de sentencias estudiadas sobre adopciones (17) como se adelantó, garantizaron el derecho del niño a ser escuchado y no solo escuchado, sino que se tomó el consentimiento de éste, en dichos procesos, pero al sustraer esta cifra de la muestra total (43), el número de sentencias se reduce a 26 y en el $46 \%$ (I2) de ellas, no se garantizó el derecho del niño a ser escuchado, de forma que se torna más evidente el hecho de que tal derecho y garantía procesal de carácter vinculante, no está siendo garantizado apropiadamente por las autoridades judiciales.

7. Los progenitores, la Procuraduría de Familia y el Ministerio de la Familia, representan intereses generales y la ausencia de los progenitores o contraposición de sus intereses con los del hijo menor de edad, no ha de vedar el derecho del niño, niña o adolescente de ser escuchado en todo proceso cuyos derechos afecte y que su opinión sea un elemento más a considerar para toma de la decisión judicial, la que deberá motivarse, dando cuenta de las razones por las que se acoge o no la opinión de aquel y ha de fundamentarse jurídicamente dicha decisión, tal como lo ordena el art. 34 . 8 de la Constitución Política de Nicaragua.

8. Existe una escasa invocación de la norma convencional sobre los derechos de la niñez y adolescencia y las Observaciones Generales del Comité de los Derechos del Niño, pero sí de la norma legal; sin embargo, en aquellas sentencias en las que no se escuchó al niño, niña o adolescente, se invoca su interés superior como sustento de la decisión, lo 
que denota desconocimiento del contenido de los criterios interpretativos emanados del Comité en sus observaciones generales, sobre el derecho del niño a ser escuchado, como sobre el citado interés superior del niño, niña o adolescente.

9. Es necesario contar con un protocolo de actuaciones con niños, niñas y adolescentes en el proceso de familia, a fin de procurar homogeneidad en la práctica jurisdiccional, lo que contribuiría a la observancia del debido proceso, a la materialización del derecho de éstos a ser escuchados y una tutela judicial efectiva, respetuosa de sus derechos y por ende de su interés superior.

10. Es necesario brindar capacitación continua, especializada a las y los operadores del sistema de justicia de familia, a todos los niveles, a fin de desarrollar o fortalecer capacidades tendentes a posibilitar el ejercicio, proteger y tutelar sin discriminación alguna los derechos de niñas, niños y adolescentes en la justicia de familia.

\section{Referencias bibliográficas}

Abboud Castillo, N. L. (2016). El Cuidado Compartido. Especial Referencia al Derecho Nicaragüense. Tesis inédita de doctorado. (Facultad de Derecho. Universidad de la Habana). Cuba.

Andrade, A. (20I2). El rol estratégico del juez en los procesos de adopción. La Ley Patagonia, (589). Recuperado de:

Bustos Pueche, J. E. (1997). Manual sobre bienes y derechos de la personalidad. Madrid: Dykinson.

Cárdenas Velásquez, B. G. (20II). La jerarquía normativa de los Tratados sobre Derechos Humanos en la Constitución y la Jurisprudencia de Nicaragua. Revista de Derecho, 15. Recuperado de: http://repositorio.uca.edu.ni/807///73-94.pdf

Centro de Información Judicial. Agencia de Noticias del Poder Judicial. (2015). Nuevo Código Civil y Comercial: revocan fallo que ordenaba a una menor a mantener contacto con su madre. Argentina. Recuperado de: http://www.cij.gov.ar/nota-I7595-Nuevo-C-digo-Civil-yComercial--revocan-fallo-que-ordenaba-a-una-menor-a-mantener-contacto-con-sumadre.html

Código de Familia. Publicado en La Gaceta Diario Oficial No. 190, del 8 de octubre de 2014. Nicaragua.

Código de Familia. Publicado en el Diario Oficial No. 677, Tomo: 321, del 13 de diciembre de 1993 y sus reformas por D.L. No. 956, del 03 de febrero de 2006, publicado en el Diario Oficial No. 37, Tomo: 370, del 22 de febrero de 2006. El Salvador. Recuperado de: http://www.asamblea.gob.sv/eparlamento/indice-legislativo/buscador-de-documentoslegislativos/codigo-de-familia

Código de Familia. Publicado en el Diario Oficial La Gaceta No.24, 394, del 16 de agosto de 1984. Honduras. Recuperado de: http://www.refworld.org/pdfid/5729b6724.pdf

Código de las familias y del proceso familiar, del 19 de noviembre de 2014. Bolivia. Recuperado de: https://bolivia.infoleyes.com/norma/5268/c\%C3\%B3digo-de-las-familias-y-delproceso-familiar-cfpf

Código de la Niñez y la Adolescencia. Publicado en La Gaceta Diario Oficial No. 97, del 27 mayo de 1998. Nicaragua.

Código de la Niñez y la Adolescencia. Publicado en La Gaceta No. 26, de 6 de febrero de 1998. Costa Rica. Recuperado de: http://www.oas.org/dil/esp/codigo_ninez_adolescencia_costa_rica.pdf 
Código de la niñez y la adolescencia. Honduras, aprobado el 30 de mayo de 1996. Recuperado de http://www.poderjudicial.gob.hn/CEDIJ/Leyes/Documents/C\%C3\%B3digo\%20de\%20la\% 20Ni\%C3\%Bl ez\%20y\%20la\%20Adolescencia\%20(Actualizado\%2020I4).pdf

Constitución Política de Nicaragua de 1987, con sus reformas incorporadas. Publicada en La Gaceta Diario Oficial No. 32, del 18 de febrero de 2014. Nicaragua.

Corte Interamericana de Derechos Humanos. Sentencia de 27 de abril de 2012. Caso Fornerón e hija vs. Argentina. (Fondo, Reparaciones y Costas). Recuperado de: http://corteidh.or.cr/docs/casos/articulos/seriec_242_esp.pdf

Corte Interamericana de Derechos Humanos, OEA. (s.f.). Cuadernillo de jurisprudencia de la Corte Interamericana de Derechos Humanos No. 5: Niños y Niñas. Recuperado de: http://www.sitioswwweb.com/miguel/ninosninas3.pdf

Convención sobre los Derechos del Niño. Adoptada el 20 de noviembre de 1989. Recuperado de: www.ohchr.org/SP/Professionallnterest/Pages/CRC.aspx

Convenio Europeo de Derechos Humanos. (1950). Recuperado de: http://www.echr.coe.int/Documents/Convention_SPA.pdf

De Carlo, I. L. (20I4). Derecho del menor a ser oído. Una hermenéutica efectiva. Recuperado de: http://www.saij.gob.ar/ivan-lucas-carlo-derecho-menor-ser-oido-una-hermeneuticaefectiva-dacfl 40869-20 I4-I2-03/ 23456789-0abc-defg9680-

Declaración de los Derechos del Niño. (1959). Recuperado de: http://www.humanium.org/es/wp-content/uploads/2013/09/Declaraci\%C3\%B3n-de-losDerechos-del-Ni\%C3\%Blol.pdf

Decreto No. I,065/ 982. Ley reguladora de las relaciones entre madre, padre e hijos. Nicaragua. Recuperado de: http://sajurin.enriquebolanos.org/vega/docs/JGRN_1065.pdf

Decreto No. 415/06. Protección Integral de los Derechos de Niñas, Niños y adolescentes. Apruébase la reglamentación de la Ley $\mathrm{N}^{\circ}$ 26.06I. Argentina. Recuperado de: https://www.oas.org/dil/esp/decreto_415-06_argentina.pdf

De Espanés, L. M. \& Hiruela de Fernández, M. P. (s.f.). Derechos de la personalidad. Recuperado de: http://www.revistapersona.com.ar/Persona46/46Moisset.htm\#N_I_

Espada Mallorquín, S. (2015). La efectiva aplicación del derecho del menor a ser oído. Corte Suprema, 18 de agosto de 20I5, rol I24-20I5.Revista chilena de derecho privado, (25). Recuperado de: http://www.scielo.cl/scielo.php?script=sci_arttext\&pid=S07 I880722015000200011

Famá, María V. (2009). Alcances de la participación de los niños y adolescentes en los procesos de familia. Recuperado de: http://www.villaverde.com.ar/archivos/File/novedades/fallocoment-fama-salal-arts I 2CDN-27Ley2606I.doc

Gascón Abellán, M., \& García Figueroa, A. (2013). Interpretación y Argumentación Jurídica. Consejo Nacional de la Judicatura. Recuperado de: http://cnj.gob.sv/index.php/novedades/publicaciones/244-interpretacionyargumentacion-juridica

González Contró, M. (20I5). Los derechos fundamentales del niño en el contexto de la familia. Recuperado https://www.researchgate.net/publication/26794I677_LOS_DERECHOS_FUNDAMENT ALES_DEL_NINO_EN_EL_CONTEXTO_DE_LA_FAMILIA

Herrera, M. (20I I). "La democratización de las relaciones de familia. Desafios de la relación padres e hijos desde el principio de capacidad progresiva de niños, niñas y adolescentes". Recuperado de: 
https://www.google.com.ni/search?q=derecho+del+ni\%C3\%Blo+a+ser+oido,+PELLEG RINI\&ei=4oaQWd3 IJMvymAGJs52wDQ\&start $=10 \&$ sa $=$ N\&biw $=1024 \& b i h=573 \#$

lustel $(2015,20$ de febrero). El TS declara la necesidad de oír a los menores antes de resolver sobre la solicitud de custodia compartida. Diario del Derecho. Recuperado de: http://www.iustel.com/diario_del_derecho/noticia.asp?ref_iustel=| I 37489

Juzgado Primero de Distrito de Familia (oralidad) de la circunscripción Managua. Sentencia No. $0213 / 2016$, de las dos y quince minutos de la tarde, del 15 de junio de 2016. Nicaragua.

Juzgado Tercero de Distrito de Familia (oralidad) de la circunscripción Managua. Sentencia S/N, de las cuatro y cincuenta y tres minutos de la tarde, del l4 de Octubre de 2016. Nicaragua.

Juzgado Cuarto de Distrito de Familia (oralidad) de la circunscripción Managua. Sentencia S/N, de la una y treinta y nueve minutos de la tarde, del 12 de diciembre de 2016. Nicaragua.

Juzgado Quinto de Distrito de Familia (oralidad) de la circunscripción Managua. Sentencia No.0488/2016, de las dos y treinta minutos de la tarde, del 19 de septiembre de 2016. Nicaragua.

Juzgado Quinto de Distrito de Familia (oralidad) de la circunscripción Managua. Sentencia No. 0538/2016, de las doce y dieciséis minutos de la tarde, del 25 de octubre de 2016. Nicaragua.

Juzgado Sexto Distrito de Familia (oralidad) de la circunscripción Managua. Sentencia No. 0287/2016, de las nueve y diez minutos de la mañana, del 03 de octubre de 2016. Nicaragua.

Juzgado Séptimo de Distrito de Familia (oralidad) de la circunscripción Managua. Sentencia S/N, de las diez y catorce minutos de la mañana, del 25 de noviembre 2016. Nicaragua.

Juzgado Octavo de Distrito de Familia (oralidad) de la circunscripción Managua. Sentencia No. $0014 / 2016$, de las ocho y cinco minutos de la mañana, del 13 de abril del 2016. Nicaragua.

Juzgado Octavo de Distrito de Familia (oralidad) de la circunscripción Managua. Sentencia No. 0175 , de las once y treinta y cinco minutos de la mañana, del 30 de septiembre del 2016. Nicaragua.

Juzgado Noveno de Distrito de Familia (oralidad) de la circunscripción Managua. Sentencia No. 0024/2016, de las tres y veintitrés minutos de la tarde, del doce de Mayo de 2016. Nicaragua.

Juzgado Noveno de Distrito de Familia (oralidad) de la circunscripción Managua. Sentencia No. 0222/2016, de las diez y cincuenta y dos minutos de la mañana, del 19 de diciembre del año 2016. Nicaragua.

Juzgado Décimo de Distrito de Familia (oralidad) de la circunscripción Managua. Sentencia No. 0202/2016, de las dos de la tarde, del 02 de diciembre de 2016. Nicaragua.

Juzgado Primero Distrito de Familia (oralidad) de la circunscripción Managua. Sentencia No. 0169/2016, de la una y tres minutos de la tarde, del 13 de mayo de 2016. Nicaragua.

Juzgado Segundo de Distrito de Familia (Oralidad) de la circunscripción Managua. Sentencia $N^{\circ}$ 284/2016, de las nueve y veintinueve minutos de la mañana del once de julio de 2016. Nicaragua.

Juzgado Cuarto de Distrito de Familia (Oralidad) de la circunscripción Managua. Sentencia No. 0126/2016, de las cuatro y un minutos de la tarde, del II de marzo de 2016. Nicaragua. 
Juzgado Quinto de Distrito de Familia (oralidad) de la circunscripción Managua. Sentencia No. 0436/2016, de las cuatro y cincuenta y ocho minutos de la tarde, del 03 de agosto de 2016. Nicaragua.

Juzgado Sexto Distrito de Familia (oralidad) de la circunscripción Managua. Sentencia No. $0190 / 2016$, de las diez y treinta y tres minutos de la mañana, del 30 de junio de 2016. Nicaragua.

Juzgado Séptimo Distrito de Familia (oralidad) de la circunscripción Managua. Sentencia No. 0005/2017, de las nueve y cuarenta y cuatro minutos de la mañana, del 23 de enero de 2017. Nicaragua.

Juzgado Octavo de Distrito de Familia (oralidad) de la circunscripción Managua. Sentencia No. 0070/20I6, de las ocho y cincuenta minutos de la mañana, del I4 de junio del 2016. Nicaragua.

Juzgado Octavo de Distrito de Familia (Oralidad) de la circunscripción Managua. Sentencia No. 0024/2017, de las diez de la mañana, del 27 de enero de 2017. Nicaragua.

Juzgado Noveno de Distrito de Familia (Oralidad) de la circunscripción Managua. Sentencia No. $0176 / 2016$, de las doce y doce minutos de la tarde, del Olde noviembre de 2016. Nicaragua.

Juzgado Noveno de Distrito de Familia (Oralidad) de la circunscripción Managua. Sentencia No. $0219 / 2016$, de la una y cincuenta y un minutos de la tarde, del 15 de diciembre del año 2016. Nicaragua.

Juzgado Décimo Distrito de Familia (oralidad) de la circunscripción Managua. Sentencia No. $0014 / 2017$, de las tres y veinticinco minutos de la tarde, del 25 de enero de 2017. Nicaragua.

Juzgado Décimo Distrito de Familia (oralidad) de la circunscripción Managua. Sentencia No. $0021 / 2017$, de las ocho y veintiséis minutos de la mañana, del 30 de enero de 2017. Nicaragua.

Juzgado Primero Distrito de Familia (oralidad) de la circunscripción Managua. Sentencia No. 160/2016, de las doce y quince minutos de la tarde, de 10 de mayo de 2016. Nicaragua.

Juzgado Primero Distrito de Familia (oralidad) de la circunscripción Managua. Sentencia No. $334 / 2016$, de las dos y cinco minutos de la tarde, del 22 de septiembre de 2016. Nicaragua.

Juzgado Segundo Distrito de Familia (oralidad) de la circunscripción Managua. Sentencia No. $454 / 2016$, de las cuatro de la tarde, del 28 de noviembre de dos mil dieciséis. Nicaragua.

Juzgado Cuarto de Distrito de Familia (Oralidad) de la circunscripción Managua. Sentencia No. $\mathrm{S} / \mathrm{N}$, de las tres y dieciséis minutos de la tarde, del 21 de julio de 2016. Nicaragua.

Juzgado Quinto Distrito de Familia (oralidad) de la circunscripción Managua. Sentencia No. 479/2016, de las diez y diecisiete minutos de la mañana, del 12 de septiembre de 2016. Nicaragua.

Juzgado Séptimo Distrito de Familia (oralidad) de la circunscripción Managua. Sentencia No. $\mathrm{S} / \mathrm{N}$, de las tres y treinta minutos de la tarde, de 21 de octubre 2016. Nicaragua.

Juzgado Octavo de Distrito de Familia (oralidad) de la circunscripción Managua. Sentencia No.0246/2016, de las tres y diecisiete minutos de la tarde, del I 3 de diciembre de 2016. Nicaragua.

Juzgado Noveno de Distrito de Familia (oralidad) de la circunscripción Managua. Sentencia No. 0004/2016, de las doce y dieciséis minutos de la tarde, del 07 de abril de 2016. Nicaragua.

Juzgado de Distrito de Familia de Matagalpa, circunscripción Norte. Sentencia No. 065, de las once y treinta y dos minutos de la mañana, del 22 de mayo de 2017. Nicaragua. 
Juzgado de Distrito de Familia de Matagalpa, circunscripción Norte. Sentencia No. 079, de las once y siete minutos de la mañana, del 13 de junio de 2017. Nicaragua.

Juzgado de Distrito de Familia de Matagalpa, circunscripción Norte. Sentencia No. II2, de las diez y cuarenta minutos de la mañana, del II de octubre de 2016. Nicaragua.

Juzgado de Distrito de Familia de Bluefields de la circunscripción RACCS. Sentencia No. 057, de las once y veinte minutos de la mañana, del 4 de abril de dos 2016. Nicaragua.

Juzgado de Distrito de Familia de Bluefields de la circunscripción RACCS. Sentencia No. 167, de las doce del mediodía, de 30 de agosto de 2016. Nicaragua.

Juzgado de Distrito de Familia de Bluefields de la circunscripción RACCS. Sentencia No. 216, de las once y cuarenta minutos de la mañana, del 4 de noviembre de 2016. Nicaragua.

Juzgado de Distrito de Familia de Jinotepe. Sentencia No. 275, de las nueve de la mañana, del 12 de septiembre de 2016. Nicaragua.

Juzgado de Distrito de Familia de Jinotepe. Sentencia No. 37, de las tres y dos minutos de la tarde, del 9 de febrero de 2016. Nicaragua.

Juzgado de Distrito de Familia de Jinotepe. Sentencia No. 402, de las nueve de la mañana, del 20 de diciembre de 2016. Nicaragua.

Kemelmajer de Carlucci, A. \& Molina de Juan, M. F. (2015). La participación del niño y el adolescente en el proceso judicial. RCCyC, (3). Recuperado de: http://www.pensamientocivil.com.ar/system/files/2016/02/Doctrina2293.pdf

Kemelmajer de Carlucci, A. \& Pérez Gallardo, L. B. (Coord.). (2006). Nuevos perfiles

del derecho de familia. Recuperado de: http://www.lex.uh.cu/sites/default/files/2006KEMELMAJER Y PÉREZ GALLARDO - L.Hom_.O. Mesa.pdf

Ley de protección integral de la niñez y adolescencia, aprobada el 4 de junio de 2003.

Guatemala. Recuperado de:

https://www.oas.org/dil/esp/Ley_de_Proteccion_Integral_de_la_Ninez_y_Adolescencia _Guatemala.pdf

Ley de protección integral de la niñez y adolescencia. Publicado en el Diario Oficial No. 68, Tomo 383, del 16 de abril de 2009. El Salvador. Recuperado: http://www.asamblea.gob.sv/eparlamento/indice-legislativo/buscador-de-documentoslegislativos/ley-de-proteccion-integral-de-la-ninez-y-adolecencia

Ley de reforma parcial a la Constitución Política de la República de Nicaragua. Ley No. 192, aprobada el I de febrero de 1995. Publicado en La Gaceta Diario Oficial No. 124, del 4 de Julio de $1995 . \quad$ Recuperado de: http://legislacion.asamblea.gob.ni/normaweb.nsf/(\$All)/927804DC295D0AE5062573080 056DA6D? OpenDocument

Ley de protección integral de la niñez y adolescencia. Publicado en el Diario oficial No. 68, Tomo No. 383, del 16 de abril de 2009. El Salvador. Recuperado de: http://www.asamblea.gob.sv/eparlamento/indice-legislativo/buscador-de-documentoslegislativos/ley-de-proteccion-integral-de-la-ninez-y-adolecencia

Ley No. 26.06I. Ley de protección integral de los derechos de las niñas, niños y adolescentes, publicada el 26 de octubre de 2005. Argentina. Recuperado de: https://www.oas.org/dil/esp/Ley_de_Proteccion_Integral_de_los_Derechos_de_las_Ni nas_Ninos_y_Adolescentes_Argentina.pdf

Ley No.19968. Crea los Tribunales de Familia, del 30 de agosto de 2004. Chile. Recuperado de: https://www.leychile.cl/Navegar?idNorma $=229557$ 
O’Donnell, D. (2004). La Doctrina de la Protección Integral y las normas jurídicas vigentes en relación a la familia. Recuperado de: https://archivos.juridicas.unam.mx/www/bjv/libros/5/2467/8.pdf

Organización de Naciones Unidas. Comité de los Derechos del Niño. Observación general $\mathrm{N}^{\circ}$ 12 (2009). El derecho del niño a ser escuchado. Recuperado de: http://www.acnur.org/fileadmin/scripts/doc.php?file=fileadmin/Documentos/BDL/20I I/7 532

Organización de Naciones Unidas. Comité de los Derechos del Niño. Observación general $N^{\circ} 14$ (20/3) sobre el derecho del niño a que su interés superior sea una consideración primordial (artículo 3, párrafo l). Recuperado de: http://tbinternet.ohchr.org/_layouts/treatybodyexternal/Download.aspx?symbolno=CR C\%2fC\%2fGC\%2fl 4\&Lang=en

Pellegrini, M. V. (2008). La figura del abogado del niño y el carácter de parte de niños y adolescentes. Recuperado de: http://www.dupratpellegrini.com.ar/publicaciones/MVP-La-figura-delabogado-del-ni\%C3\%B lo-y-el-caracter-de-parte-Uba-junio-2008.pdf

Resolución de la Corte Interamericana de Derechos Humanos, de 29 de noviembre de 2011. Caso Atala Riffo e hijas vs. Chile. Participación de las niñas. Recuperado de: www.corteidh.or.cr/docs/asuntos/atala_29_II_II.pdf

Rivera Zamora, X. (2017). El interés superior de la niñez y la adolescencia en la justicia de familia nicaragüense. Universidad Centroamericana. UCA. Managua.

Rodríguez, V.; Román Y. \& Escorial, A. (2012). Infancia y justicia: Una cuestión de derechos. Los niños y las niñas ante la administración de justicia en España. España: Save the Children. Recuperado de: http://www.cje.org/descargas/cje3 I43.pdf

Salum Alvarado, E.; Salum Alvarado, S. \& Saavedra Alvarado, R. (20I5). Derecho de los niños y las niñas a ser oídos en los Tribunales de Familia chilenos: la audiencia confidencial. Revista Latinoamericana de Derechos Humanos, 26 (2). Recuperado de: http://www.revistas.una.ac.cr/index.php/derechoshumanos/article/view/8022

Save de Children (2016). Convención sobre los Derechos del Niño. Recuperado de: https://www.savethechildren.es/trabajo-ong/derechos-de-la-infancia/convencion-sobrelos-derechos-del-nino

Sent. S/N, del 20 de septiembre de 2016. Sección tercera del Tribunal Europeo de Derechos Humanos. Asunto Iglesias Casarrubios y Cantalapiedra Iglesias C. España. Estrasburgo. Recuperado

de: https://www.idhc.org/img/butlletins/files/CASE\%200F\%20IGLESIAS\%20CASARRUBIOS \%20AND\%20CANTALAPIEDRA\%20IGLESIAS\%20v.\%20SPAIN\%20\%20-

\%20\%5BSpanish\%20Translation\%5D\%20by\%20the\%20Spanish\%20Ministry\%20of\%20Just ice\%28I\%29.pdf

Suprema Corte de Justicia de la Nación. (2012). Protocolo de actuación para quienes imparten justicia en casos que afectan a niños, niñas y adolescentes. México. Recuperado de: http://www.pjetam.gob.mx/tamaulipas/interiores/Publicaciones/Protocolo2012_v3.pdf

Suprema Corte de Justicia de la Nación, (20l4). Protocolo iberoamericano de actuación judicial para mejorar el acceso a la justicia de personas con discapacidad, migrantes, niñas, niños, adolescentes, comunidades y pueblos indígenas. México. Recuperado de: https://www.sitios.scjn.gob.mx/codhap/sites/default/files/banner/archivos/Protocolo_lbe roamericano.pdf

Tribunal de Apelaciones circunscripción Managua, Sala Civil número Dos. Sentencia No. 003, de las diez de la mañana, del 3 de febrero de 2016. Nicaragua. 
Tribunal de Apelaciones circunscripción Managua, Sala Civil número Dos. Sentencia No. 0012, de las nueve de la mañana, de 17 de enero de 2017. Nicaragua.

Vargas Pavez, M. \& Correa Camus, P. (20II). "La voz de los niños en la justicia de familia de Chile". lus et Praxis, 17, (I). Recuperado de: http://www.scielo.cl/scielo.php?script=sci_arttext\&pid=S07 I $8-00122011000100008$ 